Bangladesh J. Plant Taxon, 21(2): 197-198, 2014 (December)

(C) 2014 Bangladesh Association of Plant Taxonomists

\title{
TWO NEW COMBINATIONS IN THE GENUS CHIONANTHUS L. (OLEACEAE)
}

\author{
Bui Hong Quang, Ritesh Kumar Choudhary ${ }^{1}$, Vu Tien Chinh, Tran The Bach, \\ Tran Thi Phuong AnH ${ }^{2}$ And JoOngKu LeE ${ }^{3,4}$ \\ Department of Botany, Institute of Ecology and Biological Resources, Vietnam Academy of \\ Science and Technology, 18 Hoang Quoc Viet, CauGiay, Hanoi, Vietnam \\ Keywords: Oleaceae; Chionanthus; New combinations; Vietnam.
}

The genus Chionanthus L. is distributed in tropical and subtropical regions of America, Africa, Asia and Australia, and is represented by 80 species (Mabberley, 2008). Indeed, the species number of this genus increased considerably by the merger of the genus Linociera Swartz, based on the survey of morphological and palynological characters by Stearn (1976). Later, Chang et al. (1996) in Flora of China accepted the reduction of Linociera with Chionanthus although the former are deciduous and found in temperate Asia and North America and the later are evergreen and pantropical.

In Vietnam, the genus Chionanthus s.l. is represented by 15 species (Ho, 2000; Ly, 2003). Though most of the species described under the genus Linociera were found to be transferred to Chionanthus, two species Linociera robinsonii Gagnep. and L. subcapitata Merr. described in the year 1933 and 1942 respectively from Indo-China (Vietnam) are yet to be transferred formally, which necessitates the following new combinations.

Chionanthus robinsonii (Gagnep.) B.H. Quang, comb. nov.

Basionym: Linociera robinsonii Gagnep. Bull. Soc. Bot. France 79: 787 (1933).

Type: Vietnam. Nha Trang and vicinity: (Amamite) Yacnai, Small tree at $100 \mathrm{~m}$ elevation, 11 March 2011, C.B. Robinson 1419 (Holotype: P-Photo!).

Notes: Chionanthus robinsonii is endemic to Vietnam and needs utmost attention for conservation.

Chionanthus subcapitata (Merr.) B.H. Quang, comb. nov.

Basionym: Linociera subcapitata Merr., J. Arnold Arbor. 23: 189 (1942).

Type: Vietnam. Ven 1200 m (Mau Son) Province de Lang Son Tonkin, 1925, A. Ptelot 1720 (Holotype: K-Photo!; Isotype: VNM!).

Notes: Chionanthus subcapitata is also endemic to Vietnam and scarcely distributed throughout its altitudinal limits. More floristic surveys are required to know its real population status.

\footnotetext{
${ }^{1}$ Agharkar Research Institute, G.G. Agarkar Road, Pune-411004, India

${ }^{2}$ Vietnam National Museum of Nature, Vietnam Academy of Sciences and Technology, 18 Hoang Quoc Viet, Nghia Do, CauGiay, Hanoi, Vietnam

${ }^{3}$ International Biological Material Research Center, Korea Research Institute of Bioscience and Biotechnology, 125 Gwahak-ro, Yuseong-gu, Daejeon, South Korea

${ }^{4}$ Corresponding author. Email: joongku@kribb.re.kr
} 


\section{Acknowledgements}

We are thankful to the curator of herbarium VNM for allowing us to examine the voucher specimens.We also acknowledge the research funding granted by the Vietnam National Foundation for Science and Technology Development (NAFOSTED) under grant number 106.112012.37; and Korea Research Institute of Bioscience \& Biotechnology, Korea under project on 'Bio-prospecting on biological materials of Vietnam'.

\section{References}

Chang, M.C., Qui, L.Q., Wei, Z. and Green, P.S. 1996. Oleaceae. In: Wu, Z. and Raven, P.H. (Eds), Flora of China, Vol. 15. Science Press, Beijing, China and Missouri Botanical Garden, Missouri, USA, pp. 272319.

Ho, P.H. 2000. Oleaceae. In: An illustrated flora of Vietnam.Vol. 2. Mekong Press, Montreal, pp. 883-886.

Mabberley, D.J. 2008. Mabberley’s Plant-book: a portable dictionary of plants, their classification and uses. Cambridge University Press, England, 1004 pp.

Ly, T.D. 2003. Checklist of Plant Species of Vietnam, Vol. 2. Agricultural Publishing House, Hanoi, 1169 pp. Stearn, W.T. 1976. Union of Chionanthus and Linociera (Oleaceae). Ann. Miss. Bot. Gard. 63(2): 355-357.

(Manuscript received on 21 April 2014; revised on 1 October 2014) 